\title{
REMOTE TEACHING FOR THE NEW NORMAL SOCIETY: A PARADIGM SHIFT IN HIGHER EDUCATION
}

\author{
Suramya Mathai\#1 \& Nimmi Maria Oommen\#2 \\ \#1Asst. Professor, Titus II Teachers College, Tiruvalla, \\ suramyamathai@gmail.com \\ \#2Asst. Professor, Titus II Teachers College, Tiruvalla \\ drnimmioommen@gmail.com
}

\begin{abstract}
Covid 19 pandemic has brought drastic changes in the life of people all over the world. Though it has created imbalances in all fields of life, we are in the threshold of a new normal life. The virus has made people fall to social, emotional and psychological crisis. Drastic changes have been occurred in the field of education also. The conventional classroom teaching has changed to online mode of education and the paradigm shift in education is being welcomed and practised by the educators, parents and students. This paper focusses on the paradigm shift happened in the higher education sector, challenges in the field of higher education and remote teaching for the new normal society, particularly in the Covid scenario.
\end{abstract}

Key Words: New Normal Society, Remote Learning, Covid 19, Higher education, New normal higher education

\section{Introduction}

Covid 19 pandemic has created a situation where people are locked down in their homes, reducing social interactions to the minimum. Social distancing and restricted people movements have created a state of psychological imbalance along with financial crisis, educational and occupational challenges. Mental health issues too have increased. Due to the fear about the virus, people have also become prone to depression and unexplained anxiety attacks. In India 'The National Commission for Women' has raised an urgent alert about the increasing number of domestic violence cases since the national lock down began. Consequently people have started thinking, discussing, learning and researching more on issues related to gender, stereo types, social cohesion etc. 


\section{New Normal Society}

The term 'new normal' simply means a state where an economy or society settles down after a crisis. And the new normal is different from the state existed before the crisis. Now we are in a 'new normal' state following the Novel Corona Virus Attack. The year 2020 has already been earmarked as 'the worst' year in the 21st century. The coronavirus has given rise to a global pandemic that has destabilized every field of life especially education sector and institutionalised learning. Humans have reached the most advanced stage of science and technology, but still, a virus invisible to the naked eye has massively disrupted economies, healthcare, and education systems worldwide. This should serve as a reminder that as we keep making progress in science, technology and research, humanity will continue to face challenges even in the future. So we need to prioritize the most relevant issues and to find out the solutions for survival.

The outbreak of Corona virus has made the health care sector of every nation more active and vigilant. The primary objective of any healthcare system is to provide treatment and other health related services affordable and accessible to all. The pandemic has created a real challenge in this regard as millions of people are getting affected by the virus every day. A new situation has arrived where governments need to invest more in health and education and simultaneously reduce expenditure on many other sectors. There is substantial evidence that increased investment in health and education is beneficial in the long-term and can potentially build the basic foundation of a country.

It is almost two years since we are affected and locked down by the 'Corona Attack'. Hence our immediate focus should be to tackle the complex problems that have emerged from the pandemic so that we can make recovery more fast and easy.

We are slowly returning back to the track by managing transportation, educational, industrial and commercial sectors recover to the new normal. Educational institutions are about to open and set to start hopefully by the beginning of the New Year. We can see that countries are emerging stronger with greater understanding of public good. People have transformed to be more hygienic and have started taking more healthy food. This has improved the immunity of the general public and many diseases which were common to the public earlier had now been vanished from the scene. Also, people have realised the shortcomings of materialistic life and learned that they can live more simple and healthy. It seems that we cannot go back to an India before the coronavirus struck. There will be a new normal and it will be very different from the normal of the pre-corona times. Hence we can say that we are moving towards new normal which we could never think about before; new and better health care, new life style, new modes of education, new ways of keeping relations by physically distancing from each other and mentally being close, new work patterns, new modes of sales and a new understanding among nations regarding handling the virus. Among all the changes, the most important and noticeable one is the greater reliance on remote learning and online education. 


\section{Features and Challenges of the New Normal Higher Education}

The Higher Education sector is also limping back to normalcy with greater emphasis given to remote learning. 'The new normal' is an entirely different one from the pre Covid normal, which we never imagined or were prepared for. Classes are going on somewhat smoothly and admissions and examinations are carried out in online modes. Remote and Blended learning approaches are being adopted to ensure uninterrupted learning experiences to students. Educational institutions have no choice but to connect to students via the online medium. Education has really become remote, flexible and resilient as a result of the Covid 19 pandemic. Education all around the world has become completely online in nature. In the beginning there was much ambiguity about what to teach, how to teach, when to teach and the work loads of teachers as well as students. Lack of gadgets, absence of internet connections and weak connectivity created challenges to the new mode of teaching learning process. Lack of experience of teachers, challenging home environments and hesitance to accept change worsened the situation. But government had taken a strong stand and started online classes for all grades to guarantee that education of students are not affected anymore. Action plans were formulated for finding out the learning difficulties of students and to a great extent corrective measures were also adopted. Training sessions were arranged for teachers at various levels to cope up with the new modes of teaching learning process. When schools and colleges were shut down to avoid the spread of Corona Virus, we have no other option but to resort to both formal and informal flexible teaching and learning. As the new generation is more techno savvy, the difficulty of online education is more faced by the teaching community. Even senior citizen and parents find it difficult to monitor the online education of their wards. Capturing and maintaining the attention of students was the most important challenge faced by the teachers. To overcome these challenges teachers need to acquire new ICT related skills and create a congenial learning environment which looks attractive to students. They also need to get familiarised with various online teaching platforms, tools and teaching approaches so as to meet the requirements of the students. At any cost institutions must transform themselves to be innovative and digitally equipped centres of learning. As remote learning has become the need of the hour rather than protesting against the online education, it is better to transform ourselves and make best use of the opportunity to learn and survive. Governments should see that no students is devoid of education and the new mode of remote learning reaches each and every student. Efforts must also be taken to scrutinise the syllabus and make it congenial for online transaction. Care must be taken that students are not over stressed and emotionally imbalanced due to any reason related to remote learning. Awareness classes may also be arranged for parents and teachers to tackle the challenges faced by children as a result of online education.

\section{Remote Learning}

We are living in an era where education is at our fingertips. The Internet makes it easier than ever to get information. Flexible online learning environments provide the scope to learn from the comforts of your home, and often around a schedule that suits your needs. In light of these recent trends, people prefer to stay at home rather than going to campus to pursue their 
education. E learning, more specifically remote learning, has become not only popular but also vital in the context of Covid 19 pandemic.

Remote teaching and learning is a situation where the student and the educator, or information source, are not physically present in a traditional classroom environment. In Remote teaching a virtual classroom is created and classes are carried out like that of a traditional classroom. Remote learning refers to educational activities that have a variety of formats and methods, most of which take place online. There are a number of online options available for communicating with students, collecting assignments, and distributing education materials. Here teaching learning is carried out using technology, such as video conferencing platforms, e- resources, discussion boards, and online assessments. Remote Learning can occur synchronously with real-time peer-to-peer interaction and collaboration, or asynchronously, with self-paced learning activities that take place independently of the instructor. Even though remote education takes place in an online mode, it is different from online education.

\section{Differences between Online Learning and Remote Learning}

\section{Remote Education}

Although remote learning also takes place online, it is different from online learning. Remote learning strives to re-create the classroom environment as the student learns through the computer. This means the student logs in to the virtual classroom environment at scheduled times to view lectures or participate in group learning activities. The coronavirus pandemic caused a rise in emergency remote learning. As colleges and universities had to shut down to protect their faculty and students, they sent students home to study remotely. Teachers teach at the pre-determined times and students watch the lectures online rather than sitting in the classroom.

\section{Online Education}

Online education takes place entirely online. Online programs are designed for students who need a flexible and self-paced education. The curriculum is generally taught using a combination of various content styles - PowerPoint presentations, discussion forums, written lectures, or scholarly articles - and is practiced through projects and online exams. Courses may use video lectures or self-paced courses to take students through their learning experiences. Some online education options move students towards certification or a degree. Others are designed for adult learners who want to gain a new knowledge or skill or polish an existing one, but without actually taking students toward an official degree. Even though online education typically does not have scheduled class times, it will have deadlines. Students will need to complete their work by certain dates but with flexible time patterns. 


\section{Benefits of Online Education}

- Online education is truly flexible and convenient

- Reduced cost of education

- It allows you to work on your own time

- Ease of content updates

- Connects you to more people and resource persons

- Makes you self-disciplined

\section{Drawbacks of Online Education}

Online education has some drawbacks.

- Lacks structure and tempts to procrastinate work

- It lacks face-to-face interaction with the instructor and may create a feeling of isolation

- Requires self- discipline and time management skills

- Reduces social interaction

- Lacks practice based learning

- Not suitable for all topics

Because of this flexibility and lack of accountability many learners in online environments fail to complete the programme. Students must be self-motivated to stick with such kinds of learning and to complete it.

\section{Benefits of Remote Learning}

- Higher level of accountability as a real classroom environment is virtually recreated

- Unlike online learning, Remote learning mirrors the structured traditional classroom

- Students can attend classes and participate in activities from anywhere

- Students receive the same curriculum from faculty as they are in classrooms

- A familiar environment may also help students feel more comfortable and productive

- Students and teachers get acquainted with various online tools and platforms

- Their digital skills develop

\section{Drawbacks of Remote Learning}

- Fails to bring all of the benefits of the real classroom

- Connectivity issues interrupts classes

- Students do not interact with their classmates unless they initiate communication online

- Remote learning also doesn't provide the flexibility of online learning 
- Rigid as classes are at the scheduled times

- Difficulty of submitting assignments and evaluating it in virtual classrooms

\section{Online Learning vs. Remote Learning}

Whether online learning or remote learning is the right choice for you is a confusing question. Both provide the benefit of learning from home, removing the commute to school and providing a measure of flexibility. Remote learning has more accountability but requires scheduled class times. Online learning has more flexibility but requires learners to be selfmotivated. To find the right one for your needs, you must weigh both options. Although remote learning has its perks - cost, efficiency, convenience - it's a form of learning that needs consideration before and during implementation.

\section{Tips for Effective Remote Education}

It may take some trial and error to adjust to remote learning, but here are some useful tips to help manage remote learning and finish courses successfully.

\section{Provide blended learning experience}

Remote learning takes traditional training methods and mixes them with modern, online techniques. So efforts must be taken to utilise the scope of blended learning. It's a blend of face-to-face interactive learning and webinars and ILT sessions. It reaches all of your remote learners provided the facilities are guaranteed. Students can ask questions, chat with one another and instructors can give instant feedback and answer queries. It's the perfect combination of old and new training techniques.

\section{Think about accessibility}

When learners are not physically present in the class room, it is difficult to teach. But we can select and use the best suitable learning software or online platforms from the available ones. Ideally, you'll need an LMS that works in a browser on a mobile or computer. But it must be accessible to all.

3. Proper Planning - Whether you prefer daily planners, to-do lists, or phone calendar reminders, it is important to stay as organized as possible. Refer to your course syllabus, plan daily activities and stick on to your plan without fail. Plan daily work in such a way that it is not a burden for teachers and students.

4. Find a suitable space for class - Even though remote learning can take place anywhere, it is important to find a space that is comfortable and can function as your remote "classroom". This could be a dining table, kitchen counter, or even a folding table in front of a favourite chair. A designated space for class helps you maintain consistency and stick to a routine. 
5. Take advantage of the apps set for class - There are many apps and platforms for conducting classes online. Select the best suitable one which offers many useful features to keep students connected and informed.

6. Be punctual- The teacher and students must be punctual in entering the class and ending the sessions. Entry of students at different times disrupts the class to a great extent. This punctuality should also be maintained from the part of learners in submitting assignments and from teachers in correcting them in the online mode.

7. Make the video option on as far as possible- This will make possible face to face contact to a great extent and make students more alert in class.

8. Use mute audio option- Make it a habit to mute audio when someone is taking class to avoid sound distractions.

9. Use ear phones or headset- It is better to avoid listening to classes in speaker mode as it disturbs others members at home. So it is better to listen to classes through ear phones.

10. Make use of different online resources simultaneously- Even though we are using a particular platform regularly for taking classes, it is advisable to use the other available resources like whatsapp, Moodle, LMS, other video conferencing platforms, e resources etc. for follow ups and extension works.

11. Keep in contact with faculty members- Since many courses follow a unique structure and meeting schedule, it's best to communicate with other faculty members regarding any specific questions you have about your courses. Always move in pace with the pattern set by the institution as a whole.

12. Keep records of online classes taken- It is advisable to keep a record book of daily classes taken in online mode for any future verification purpose and submit the same to the authorities concerned whether it is Head of the Department, Supervisor or Principal. It also helps to track the progress of the class and making any corrections required.

13. Keep in personal contact with students and get student feedbacks- Make sure that every student of your class is able to attend classes and do submissions on the date given. For this keep a personal contact with each student, talk to them over phone, listen to their problems and provide maximum support. Also collect feed backs about the kind of learning going on and make corrections if required.

14. Keep learners engaged- Out of sight is too often out of mind. This may happen in remote learning also. So take care to engage learners throughout the class using simple techniques like questioning, making individual presentations, using puzzles etc. 
15. Give notifications- One of the most effective features to encourage participation of students in remote classes is providing notifications. This is a very simple technique but highly effective in making the students alert. The teacher must give notifications about the class and submission of works through email, whatsapp, or other class groups. Again send reminders in order to prompt learners to finish their courses.

16. Make it social- Remote learning might create a feeling of soiled among the learners. Hence it's a good idea to create a more social learning environment so that learners can share their experiences and learn from one another. Let students interact with the teacher and other learners, ask questions and share resources. All this makes learning a more social experience.

\section{Conclusion}

Just like online courses, remote learning is simply an additional delivery format. Students gain the same knowledge, skills, and opportunities from online learning like real classroom learning if utilised properly. We must be hence aware of all the challenges of remote teaching and learning and adopt necessary precautionary steps to overcome them. It is vital that we consider even this fatal situation created by the pandemic as an opportunity to learn and correct ourselves and make the 'new normal' in favour of people and environment. Let us stand together and ensure that no one is left behind.

\section{References}

Basilaia, G., Kvavadze, D. (2020). Transition to online education in schools during a SARSCoV-2 coronavirus (COVID-19) pandemic in Georgia. Pedagogical Research, 5(4), 10. https://doi.org/10.29333/pr/7937 Google Scholar

Dhawan, S. (2020). Online learning: A panacea in the time of COVID-19 crises. Journal of Educational Technology, 49(1), 5-22. https://doi.org/10.1177/0047239520934018 Google Scholar

World Health Organization (n.d.). Coronavirus disease (COVID-19) pandemic. https://www.who.int/emergencies/diseases/novel-coronavirus-2019. Accessed 15 June 2020.

Moore, M. G. (1991). Editorial: Distance education theory. The American Journal of Distance Education, 5(3), 1-6. https://doi.org/10.1080/08923649109526758.

https://tophat.com/glossary/r/remote-learning/

https://www.geneva.edu/blog/higher-education/online-education-vs-remotelearning\#: : text=Remote\%20learning\%20strives\%20to\%20re,participate\%20in\%20group\% 20learning\%20activities. 